\title{
Why Did Józef Czapski Change His View of the Skamandrites?
}

He was not a painter who wrote; he was a painter and a writer. An excellent essayist, diarist, and epistolographer. As a writer, and even as a reader, Józef Czapski matured very slowly. He gradually hatched from the world of school-set books. However, already in the 1920s and 1930s, he started developing rapidly: Józef Czapski became familiar with the vast expanses of Russian literature. He read Vasily Rozanov, Fyodor Dostoevsky, and Dmitry Merezhkovsky. He developed a particular fondness for Russian poets, they were closer to him than Polish authors, who, as he once stated, could not extract from within themselves a voice which would be the voice of a generation, his generation.

Polish futurists did not impress him, and sometimes they outraged him; possibly because he was familiar with the Russian Futurism. However, he harboured grievances against the Skamadrites (on a side note - as did Jerzy Stempowski).

To Czapki, Jan Lechon seemed to be an epigone of Romantics; he "did not trust" his poems, even those recited in Stabilsk seemed "unbearable" to him $^{1}$. Interestingly enough, he only appreciated Herostrates. He started viewing Lechon differently only after the latter one had been painfully tested by the experience of emigration. His reading of Dziennik was dramatic, filled with compassion and discontent (towards egocentrism, partial - i.e. false - exhibitionism, as well as towards biased judgements about people and works).

${ }^{1}$ J. Czapski, Lechoń i jego „Dziennik”, [in:] id., Czytając, Kraków 1990, p. 438, orginally printed: "Kultura" 1968, issue 5. 
Antoni Słonimski must have intimidated him with his scathing jokes; he clearly was not a frequent guest on the second floor at Ziemiańska. Following his master Dmitry Filosofov, a Russian philosopher, he valued Słonimski's dramas and even his reportage from the USSR (Moja podróz do Rosji).

At the very beginning, he had a falling-out with Jarosław Iwaszkiewicz regarding homo-emotional issues.

Czapski was not interested in poetry with poignant images or colours though he was a painter - nor musicality, even though he wanted to become a musician when he grew up. He was interested in the poetry of experience. From this point of view, he valued the poetry of Alexander Blok and of Zinaida Gippius, as well as of his Russian peers or somewhat younger writers. His excellent knowledge of the major literary phenomena of the pre-war Russian emigration was proven by his passing remarks which he made in later years: "[Yuri] Felzen was a writer of the young generation of that time, surely one of the most interesting, along with [Gaito] Gazdanov and [Boris] Poplavsky. The rhythm of his sentences, his breath, the type of his analysis resembled those of [Marcel] Proust. However, Felzen's Proustism was free of any traces of fashion or snobbery; there was kinship". Czapski even argued with a Russian critic regarding the description of Poplavsky's poetry; he also stressed the value of his poetry, which "had acuteness, depth and «music», enough modest sadness and brave resignation that readers immediately saw not only a writer of great stature but also an exceptional person"2.

We know also, naturally, that Czapski found the poem by Hugo von Hofmannsthal - titled Przy Sybillach królowych - important; it was also symbolistic, if one was to somewhat simplify things: fitting the philosophical stream of the poetry of the German language, from which he quoted Friedrich Hölderlin and Rainer Maria Rilke.

He was interested in apocalyptical symbolism (in Blok: "ingenious sense of the coming cataclysms" ${ }^{\text {") }}$ ) and existential symbolism ("I desire that which is not present in the world"4 - this is a quote from Gippius' poem).

In symbolism, he appreciated the challenge posed for the bourgeoisie, a perspective of escaping the boredom, pointlessness, and the banality of life. As well as the opportunity for self-expression. That was not all: it offered intuitive - even mystical - cognition. One must remember that Czapski, following Filosofov, understood the Decadent movement differently - not as a downfall but, rather, as a falling-off from the collective, the celebration of otherness.

In Russia, where he spent his period of maturation, symbolism was a broad rapid current since the 1890s or, basically, since the 1910s; later, there occurred its prolonged demise, during which it succeeded in fuelling its opposite, i.e. acmeism, and clashing with Futurism. The Skamandrites took

2 J. Czapski, Wspomnienia, [in:] id., Rozproszone. Teksty z lat 1925-1988, collection and notes by P. Kądziela, Warsaw 2005, pp. 185-186, originally printed in "Kultura" 1953, issue 4.

3 J. Czapski, Błok i swoboda tajemna, "Kultura" 1948, issue 4.

${ }^{4}$ This poem was quoted many times in articles by Dmitry Filosofov, and later in Józef Czapski's journals. 
little from symbolism as it was basically absent from our poetry and they were not interested in it (or maybe it did exist only as form, without the philosophical background?) They were more interested in the intuitive combination of Parnassianism and Futurism.

One must add that Czapski did not accept symbolism as a whole and the paintings of symbolists were unknown to him. He appreciated the poets of the first wave of symbolism (mainly Gippius) and of the third wave (mainly Blok). He seems to have missed the second wave: Fyodor Sologub or Konstantin Balmont, whose presence in Poland was the strongest as they were often - and eagerly - translated by Julian Tuwim.

He knew the poems by Anna Akhmatova and Osip Mandelstam, yet those were not the poems to which he most often returned. He would always quote (from memory) Gippius, Blon, and Andrei Bely. They belonged to an earlier generation. Perhaps he too was older than his date of birth would have one think?

A separate and special place in Czapski's world was occupied by Cyprian Kamil Norwid, a poet and author of letters. In his works, he mainly sought thoughts about life, art, history, and Poland. Surely, the most important poem for Czapski was Fatum, and the two-volume edition of the poet's letters was probably the most annotated book in Czapski's library. The same Norwid that usually did not mean much to the Skamandrites.

It is interesting that as a painter toiling over form, discussing the matters of artistic craft, immersed in art history, and interested in its changes, Czapski practically ignored the aspect of form in poetry. This was indicated by his remarks about Miron Białoszewski's output ${ }^{5}$. He did not share the belief of Ludwik Hering, his friend, in the creative power of "gibberish" (one rooted in the national Polish language - that could have been the source of misunderstandings), and was cautious about "the games" in poetry, on which, according to him, the poetics of the author of Obroty rzeczy was based. Czapski's remarks, spread over several letters, concluded in a firm gesture of rejection of the "crossword puzzle approach to the poem" and that which he called "some astounding indifference - some moral non-existence".

This meant that his praising of Czesław Miłosz' poetry was not triggered only by the sense of his community in terms of their émigré fate.

He expected gravity of poetry, which was why he reacted violently when someone suggested Jerzy Harasymowicz' poems to him. Among all the domestic post-war poets, Czapski tolerated only Zbigniew Herbert. Initially - as a person, and later - as an artistic persona; at the end of his life, he wrote to the poet that his poems moved him, that they carried a mystery which he touched using "only a few words"7.

In 1942 in Tashkent, Czapski met Russian writers evacuated from Moscow and Leningrad. Those included Akhmatova, Lydia Chukovskaya,

${ }^{5}$ Listy z 1959 roku. J. Czapski, L. Hering, Listy 1939-1982, collection by L. Murawska-Péju,

D. Szczerba, J. Juryś, P. Kłoczowski, vol. 2, Gdańsk 2017. [Letters from 1959]

${ }^{6}$ Ibid., p. 31. Emphasis original

7 J. and M. Czapskis, K. and Z. Herberts, Korespondencja, analysis and notes by J. Strzałka, Warsaw 2017, p. 107. [English version translated from Polish] 
and Aleksey Tolstoy. In the course of several meetings, he read to them and translated Polish war-time poems which reached him after he had emigrated, mainly those by Stanisław Baliński and Słonimski.

The Russians were incredibly moved. Tolstoy found in those poems a reflection of his own émigré experiences (he had wondered the world for some time already). Chukovskaya, a writer of an independent critical sense, said at that time (which Czapski recorded in his journal): "So you have found expression for that which you have experienced, we have found nothing yet"8.

At that time, an idea emerged for Czapski to develop the anthology titled Polskie wiersze wojenne [Polish War-Time Poems], which he prepared quickly, and the texts were translated. Akhmatova translated Warszawska kolęda 1939 by Baliński and it was her first poetic translation ever. A blasphemous pietà poem about a mother and her son's suffering perfectly matched the writer's fortunes and the fortunes of her imprisoned son; a poem which perfectly aligned with her intensifying narrative poem Requiem. Until his last days, Czapski read and quoted Akhmatova; he was attached to her poems about the experience of old age ${ }^{9}$. He only disliked it when she experimented, which was why he did not accept her Poem Without A Hero.

Surely, the anthology of Polish war-time poems would have been printed if it had not been for the deteriorating Polish-Soviet political relations. Eventually, the typescript has been found and published ${ }^{10}$.

The anthology includes poems by Baliński, Słonimski, Kazimierz Wierzyński (those three with the largest presence), Maria Pawlikowska-Jasnorzewska, and Lechon, to name only the authors associated with the Skamander group. Would it be possible to reconstruct the criteria according to which Czapski organised the Polskie wiersze wojenne anthology? They are not clear, especially since we do not know what he rejected. What is certain is that he chose testimony poems, usually regardless of their forms; he did not seek beauty in them. This was because he considered the absence of beauty as a virtue, as was the case later when he returned to painting and when he quoted with contentment someone's statement that he would become recorded in history as the "master of dirty rags".

The war-time poems collected by Czapski were usually coarse; their struggles with the crisis of words were evident and this applied not only to domestic texts but also those written abroad. According to the anthology's reviewers, even the aesthetics-focused poems by Baliński included "failed" lines, uttered with a lump in the throat.

Strictly war-time poems were included in the anthology not only because they had to be included. One could assume that they were truly important for Czapski. At this point, one should mention Czapski's text about painting, written in 1944, in which he admitted that during the turmoil of

\footnotetext{
8 J. Czapski, Dziennik. Manuscript. Muzeum Narodowe w Krakowie, sign. 1922.

9 In his journal, he returned several times to the poem Ostatnia róża.

10 Polskie wiersze wojenne, collected by J. Czapski, submitted for print by I. Biełow, P. Mitzner. Warsaw 2019.
} 
war he changed his mind about the - once disregarded by him - community military art ${ }^{11}$.

Possibly, he valued war-time poems so much also because they touched upon the truth by also using "just a few words", a cry, or a scream.

\section{REFERENCES}

Czapski J., Błok i swoboda tajemna, "Kultura" 1948, issue 4.

Czapski J., Czytając, Kraków 1990.

Czapski J., Dziennik. Manuscript. Muzeum Narodowe w Krakowie, sign. 1922.

Czapski J., Wspomnienia, [in:] J. Czapski, Rozproszone. Teksty z lat 1925-1988, collection and notes by P. Kądziela, Warsaw 2005, pp. 185-186, originally printed in

"Kultura" 1953, issue 4.

Czapski J., Hering L., Listy 1939-1982, collection by L. Murawska-Péju, D. Szczerba, J. Juryś, P. Kłoczowski, vol. 2, Gdańsk 2017. [Letters from 1959]

Czapskis J. and M., Herberts K. and Z., Korespondencja, analysis and notes by J. Strzałka, Warsaw 2017, p. 107. [English version translated from Polish]

Polskie wiersze wojenne, collected by J. Czapski, submitted for print by I. Biełow, P. Mitzner. Warsaw 2019.

\section{SUMMARY}

The article applies to Józef Czapski's - a Polish painter and essayist - personal literary choices; ones that often were contrary to the tastes of his generation. In 1942, after leaving the Soviet bloc, Czapski developed the anthology Polskie wiersze wojenne for Russian readers, and the events of the war caused him to change his opinion about the modern poetry. Poems by the Skamandrites, whom he had disregarded for a long time, now became the core of his collection. Having been found a few years back, the anthology was published in 2019.

\section{Keywords}

Skamandrites, Józef Czapski, Polskie wiersze wojenne, Polish Army in the East, Anna Akhmatova, Lydia Chukovskaya

Piotr Mitzner (year of birth: 1955) - literary and theatre historian, editor, poet. Since 1999, employee of the Faculty of Humanities, Cardinal Stefan Wyszyński University in Warsaw. He is the head of the Chair of European Modernism. He focuses on the biography and the output of Jarosław Iwaszkiewicz (Hania and Jarosław Iwaszkiewicz, Esej o małżeństwie, 2000;

${ }^{11}$ J. Czapski, Czytając. Kraków 1989, p. 55. Essay Zagadnienia malarskie, orginally printed: “Orzeł Biały" 1944, issue 3. 
Na progu. Doświadczenie religijne w tekstach Jarosława Iwaszkiewicza, 2003), as well as on war-time literature (Biedny jezyk, 2011) and the Polish-Russian literary contacts (Warszawski "Domek w Kołomnie", 2014; Warszawski krag Dymitra Fitosofowa, 2015). He is the editor of texts by Jarosław Iwaszkiewicz, Tadeusz Zieliński, Lew Gomolicki, Henryk Józewski, etc.

e-mail: pmitzner55@gmail.com 